идеограмма «усердно и увлеченно работать» (налаживать) логически связана с идеограммой «начать хорошо и с охотой работать, втягиваться в работу» (затягаться), а деривационно - с лексемами с общим значением 'работать хорошо, усердно, старательно' (наложно).

Репрезентанты идеограмм в словаре сопровождаются словарной статьей, которая включает в себя заголовочное слово, толкование, примеры употребления, пометы, ссылки на источники. Мы сохраняем дефиниции слов, которые были представлены в первоначальных словарных источниках, с целью демонстрации значений, зафиксированных в определенный исторический период.

DOI 10.31168/7996-2700-3.45

\author{
И. В. Ефименко \\ Институт украинского языка НАН Украины \\ Киев, Украина \\ i.yefimenko@mail.ru
}

\title{
Названия плавательных средств в славянских языках (фрагмент историко-этимологического словаря)
}

Названия плавательных средств в славянских языках имеют давнюю историю, а такой вид хозяйственной деятельности, как судостроение, был издревле известен славянам, что отразилось в богатстве терминологии этой сферы материальной культуры. Однако, несмотря на давний интерес к обозначенной группе лексики, она до сих пор комплексно не описана.

Отобранный фактический материал, прежде всего диалектный, составляют исконные славянские образования, анализ которых позволяет проследить возникновение и функционирование ряда названий плавсредств на разных славянских территориях.

Баты́ $\mathbf{z a}$, рус. диал. (приамур.) 'лодка, выдолбленная из ствола дерева', батьир ' 'то же' [СРГП, 20] - суффиксальные дериваты от бат, ср. приамур. бат 'лодка, выдолбленная из ствола дерева' [Там же], в других говорах “лодка, обычно небольших размеров, выдолбленная 
из целого ствола дерева; однодеревка' [СРНГ, 2, 139]. Последнее могло быть перенесено из хозяйственной терминологии, ср. рус. диал. бат ‘корыто или колода, из которых поят скот' [Там же] < праслав. *batъ *batati ‘бить' [ЭССЯ, 1, 164]. Названия обоих предметов материальной культуры (лодки и корыта) объединяет способ изготовления: оба выдолблены из ствола дерева или из бревна - ср. сведения о том, что батом называли «толстое выдолбленное бревно, представлявшее длинную, но узкую лодку с цилиндрическим дном и очень валкую» [СРНГ, 2, 139].

Дópa, рус. диал. (помор., арх.) 'небольшая плоскодонная лодка с широкой кормой' [СРНГ, 8, 130], белом. 'большая лодка с плоской кормой, используемая при ловле кошельковым неводом’ [Мызников, 2010,91], доры ' мн. маленькие деревянные подсобные гребные рыбацкие лодки для обслуживания крючковых и сетевых орудий прибрежного лова' [Жилинский, 1957, 17], до́рка 'небольшая гребная лодка для обслуживания рыболовных орудий’ [Клыков, 1968, 29] < праслав. *dorb *dbrati 'драть' [ЭССЯ, 5, 79-80]. Полагаем, что название плавсредства связано с технологией его изготовления, например обшивкой каркаса тонкими деревянными дощечками - дорами, ср. рус. диал. дора 'кровельная дранка' [СРНГ, 8, 127].

Кала́бýxa, укр. диал. (н.-поднепр.) 'большая лодка - дуб' [Ліпкевич, 1993, 130], рус. диал. (дон.) ‘большая лодка' [СРНГ, 12, 333] < праслав. *kolbucha - суффиксальное производное от *kolbъ 'нечто округлое, шарообразное' [Козлова, 1991, 129]. Название плавсредства, очевидно, связано с его формой.

Lupina, польск. 'небольшая лодка, малое судно', tupinka 'маленькая лодка, суденышко' [Doroszewski, 4, 335-336] < польск. tupina 'кожура, шелуха, скорлупа' [SS, 4, 142] < праслав. *lupine 'то, что содрано’ *lupiti [ЭССЯ, 16, 182]. Этот судостроительный термин возник, вероятно, в результате метонимического переноса от названия одноименного материала, использовавшегося при изготовлении плавсредства (например, для обшивки каркаса), ср. рус. диал. лу́nа 'дранка' [СРНГ, 17, 197].

Пото́nчина, укр. 'Паром' [ЕСУМ, 4, 542] - производное с суффиксом -ин(а) от глагола *потопчити(ся), ср. укр. диал. топчитися ‘топтаться' [ЕСУМ, 5, 601], или от существительного *nотопка, ср. рус. диал. пото́nки 'мн. деревянный настил на дне лодки' [СРНГ, 30, 295]. Обе вероятные основы рассматриваемого термина соотносимы 
с праслав. *potopъtati (< *topъtati) 'топтать' со следующей семантической эволюцией: ‘топтать' $\rightarrow$ 'то, по чему топчутся' $\rightarrow$ 'настил (из бревен, досок)' $\rightarrow$ 'паром’. Ср. рус. диал. пото́nчины 'мн. настил из бревен, досок и т. п. по топкому месту; толстая доска, по которой перемещают груженые тачки’ [Там же, 296].

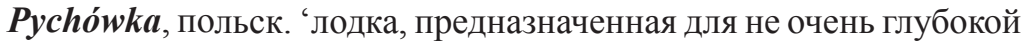
воды, сбитая из нескольких досок; плоскодонная, узкая и длинная, приводимая в движение с помощью специального весла' [Doroszewski, 7, 756] - суффиксальный дериват от глагола pychać 'толкать' [SJP, 5, 448 ] праслав. *pixati. Название плавсредства связано со способом его передвижения по воде.

Teгља̀чa, с.-х. 'буксирное судно' [Толстой, 1957, 935] - суффиксальное производное от основы причастия на -l- (ср. рус. тягльй $)<$ праслав. *tęglъjb *tegti 'тянуть'. Название плавсредства указывает на его функцию - тягу других судов или плавучих сооружений.

ЕСУМ - Етимологічний словник української мови : у 6 т. / за ред. О. С. Мельничука. Київ, 1982-2012.

Жилинский А. А. Промысловый словарь рыбаков и зверобоев Белого моря. Петрозаводск, 1957.

Кльюков А. А. Краткий словарь рыбацких слов. М., 1968.

Козлова P. M. Славянские континуанты и.-е. *(s)kel- 'гнуть, сгибать; крутить'// Studia z filologii polskiej i słowiańskiej. Warszawa, 1991. S. 127-140.

Ліпкевич I. Г. Рибальська лексика в українських говірках Нижньої Наддніпрянщини : дис. ... канд. філол. наук / Запорізький ун-т. Запоріжжя, 1993.

Мызников С. А. Русские говоры Беломорья : материалы для словаря. СПб., 2010.

СРГП—Словарь русских говоров Приамурья / отв. ред. Ф. П. Филин. М., 1983.

СРНГ - Словарь русских народных говоров / гл. ред. Ф. П. Филин (вып. 1-22) ; Ф. П. Сороколетов (вып. 23-42) ; С. А. Мызников (вып. 43-). М. ; Л. ; СПб., 1965-. Вып. 1-.

Толстой И. И. Сербскохорватско-русский словарь. М., 1957.

ЭССЯ - Этимологический словарь славянских языков: Праславянский лексический фонд / под ред. О. Н. Трубачева (вып. 1-32); А. Ф. Журавлева (вып. 33-39); Ж. Ж. Варбот (вып. 40-). М., 1974-. Вып. 1-.

Doroszewski - Słownik języka polskiego / pod red. W. Doroszewskiego. T. 1-11. Warszawa, 1958-1969.

SJP - Słownik języka polskiego / pod red. J. Karłowicza, A. Kryńskiego, W. Niedźwiedzkiego. T. 1-8. Warszawa, 1904-1927.

S S - Słownik staropolski / pod red. S. Urbańczyka. T. 1-11. Warszawa, 1953-2002. 